\section{A materialidade da cultura: uma nova forma de ler o mundo}

\section{Luiz Augusto de Oliveira Gomes}

Universidade Federal Fluminense, Faculdade de Educação, Niterói, RJ, Brasil.

$<$ luiz.augusto1201@gmail.com>

ALBURQUERQUE, Gregorio G. de; VELASQUES, Muza C. C.; BATISTELLA, Renata Reis C. (Org.). Cultura, politecnia e imagem. Rio de Janeiro: EPSJV, 2017. 318 p.

O livro Cultura, politecnia e imagem, organizado por Gregorio Galvão de Albuquerque, Muza Clara Chaves Velasques e Renata Reis C. Batistella, publicado pela Escola Politécnica de Saúde Joaquim Venâncio/Fundação Oswaldo Cruz, apresenta um panorama ampliado do conceito de cultura a partir de três eixos de análise que se complementam: (1) Cultura, educação, trabalho e saúde; (2) Cultura, educação e imagem; e, (3) Cultura e cinema. Os 20 autores que assinam os 15 artigos do livro apresentam importantes contribuições para compreender a materialidade da cultura nos tempos atuais.

No eixo "Cultura, educação, trabalho e saúde", ao debater cultura, os autores se fundamentam especialmente no materialismo histórico dialético para refletir sobre o conceito ampliado do termo. É interessante observar a defesa de uma concepção de cultura imbricada dialeticamente com todas as instâncias dos processos de produção da vida social, refutando a tradição idealista que busca na cultura algo puro e apartado do "reino dos conflitos e contradições" (p. 25). Além da crítica ao idealismo, é crucial destacar as reflexões acerca das obras de Eduard Palmer Thompson e Raymond Willians, pensadores da chamada nova esquerda britânica, para desconstruir a leitura de um marxismo dogmático e fundado no reducionismo econômico, que hierarquiza base/superestrutura e plasma a cultura no plano da 'superestrutura', desvinculada das relações sociais de produção (infraestrutura). Quanto às relações dialéticas entre estrutura e superestrutura, assim como Thompson (1979, p. 315) podemos dizer que "o que há são duas coisas que constituem as duas faces de uma mesma moeda". Ao ter em conta os nexos entre economia e cultura, podemos perceber que a "dimensão cultural das sociedades são espaços dinâmicos permeados por conflitos de interesses" (p. 88), espaços onde estão presentes tanto o consenso quanto disputas por uma nova hegemonia. Essa constatação vai ao encontro das palavras de Thompson (1981, p. 190) de que "toda luta de classes é ao mesmo tempo uma luta acerca de valores", valores esses que constituem a cultura, cuja base material deve ser investigada e considerada na análise do movimento do real.

É um desafio compreender o conceito de cultura não apenas como campo de consenso. Como nos informa o eixo "Cultura, educação, trabalho e saúde", a cultura pode ser entendida como resultado das ações dos homens e mulheres sobre o mundo. Em última instância, "ela se torna o próprio ambiente do ser humano no qual ele é formado, apropriando-se de valores, crenças, objetos, conhecimentos" (p. 99).

A obra de Clifford Geertz, trabalhada em um dos artigos do livro, também contribui para o debate sobre cultura, principalmente por abordar os modos de vida e discursos dos grupos vulneráveis ou excluídos. A noção de comportamento humano de Geertz é uma ótima ponte para aproximar a antropologia da discussão a respeito da compreensão do processo saúde-doença. A autora do artigo afirma que a contribuição de Geertz e a sua antropologia "é muito favorável para a inclusão do ponto de vista dos pacientes e usuários dos serviços na análise das questões de saúde, principalmente no atual contexto, no qual o discurso médico é dominante" (p. 114).

No segundo eixo, intitulado "Cultura, educação e imagem", os autores tratam da construção de conhecimento por meio das imagens. Esse eixo, em especial, nos favorece a compreensão das imagens como mediação em espaços formativos, sejam eles institucional (como a escola) ou qualquer outro espaço de educação dos sujeitos coletivos. Para isso, os autores buscam principalmente nas experiências em sala de aula mostrar como, por intermédio da cultura (em especial, da imagem), é possível outra leitura do mundo.

Com isso, concordamos com Kosik (1976) quando entende que compreender a vida para além da sociedade fetichizada - que toma a coisas no seu isolamento, adota a essência pelo fenômeno, a mediação pelo imediatismo-, é um exercício de apreensão da totalidade do cotidiano. Por isso, tendo em conta a pseudoconcreticidade com que o mundo se apresenta, os autores indicam que na 
sociedade capitalista, onde "o urbano passa a ser uma sucessão de imagens e sensações produzidas e reproduzidas pelos indivíduos que criam uma condição fragmentada da vida moderna" (p. 88), crianças, jovens e adultos buscam nas imagens divulgadas nas mídias (televisão e redes sociais) a construção de si mesmos e do mundo.

Na lógica do capital, a imagem exerce um papel importante na manutenção da hegemonia, impondo valores e transferindo os desejos da burguesia para a classe trabalhadora. Como constata um dos artigos, a "dissolução da forma burguesa mantém-se no contínuo da passividade dos sujeitos sociais, arraigando assim uma violência subjetiva terrorista, como reconhecer e alterar este mundo [...] a colonização estética dos sentidos é perversa" (p. 160).

Sabemos que a educação é apropriada pelo capitalismo como formadora de consenso: "forma-mercadoria e forma estatal como princípio de organização da vida social, impregnando a subjetividade humana de práticas autorrepressivas no que diz respeito aos seus impulsos de felicidade e liberdade" (p. 170). A leitura do eixo "Cultura, educação e imagem" reforça que o "viés questionador, transformador e revolucionário da reflexão e da produção cultural podem possibilitar uma nova forma de ler do mundo" (p. 143). Os artigos nos ajudam a compreender que a imagem é uma potente ferramenta, constituindo-se como mediação tanto revolucionária quanto para manter o status quo da classe econômica e culturalmente dominante.

Por fim, no último eixo, "Cultura e cinema", os autores nos convidam a conhecer a discussão acerca da cultura e da imagem com base em consistentes formulações teóricas que envolvem a produção do cinema e os seus nexos com as práticas escolares. Neste eixo, podemos destacar que é de grande importância a crítica direcionada às produções acadêmicas que corroboram para que a “análise de filmes seja percebida ainda como uma forma acessória de se atingir uma compreensão sobre a realidade social" (p. 231), ou seja, esse tipo de análise trata a produção do cinema como uma mera fonte de registro e que para compor uma análise da sociedade necessitam de outros tipos de fontes.

Em seus quatro artigos, o eixo "Cultura e cinema" procura demonstrar como a produção fílmica é uma fonte histórica de grande relevância para analisar a sociedade a partir de uma "concepção estético-política" (p. 232). Busca na interpretação do filme "Terra em Transe", do diretor Glauber Rocha, elementos importantes para a leitura dos acontecimentos do golpe empresarial-militar de 1964 e as variadas interpretações do seu sentido nos dias atuais. O filme é "uma síntese devastadora do processo de luta de classes no Brasil e na América Latina dos anos 1960 como núcleo duro permeando todas as relações sociais reais, demole todos os discursos de legitimação dos projetos colonizadores" (p. 254). A produção em questão nos ajuda a compreender a potência do cinema na captação do real e de como a organização formal e estética em imagem e som nos auxilia na percepção das disputas de classe ocorridas no período.

A concepção de romper com um olhar naturalizado sobre a sociedade de classes é um dos intuitos das produções fílmicas alternativas, em especial na conturbada América Latina do século XX. Assim, o Nuevo Cine Latinoamericano marcou o cinema latino-americano, buscando em produções militantes, conscientizar trabalhadores e trabalhadoras a sair das suas 'zonas de conforto'. Essa concepção de cinema buscou possibilitar, como nos indica um dos artigos, "uma nova leitura do mundo, e uma nova forma de pensar a nossa realidade, características fundamentais para a transformação social" (p. 287).

Assim como os longas-metragens, os documentários também contribuem para narrar os conflitos de classe. Como sinaliza uma das autoras, o documentário tem o poder de relacionar a antropologia, a arte visual e a produção cinematográfica para contar uma história. Com isso, os documentários sustentam o "mito de origem de falarem a verdade" (p. 258). Todavia, o eixo nos leva a refletir: Qual verdade? Verdade para quem? O livro nos convida a encarar o documentário como um gênero de grande importância para a pesquisa social.

O rico debate teórico com base na materialidade da cultura alicerçada nas pesquisas dos autores, seja em sala de aula ou na análise de imagens e filmes, ajuda-nos a entender a profundidade do conceito de cultura e a sua potência como agente da transformação social. $\mathrm{O}$ livro nos elucida quanto à necessidade de que a classe trabalhadora se aproprie e interprete sua própria cultura, descolonizando-se da hegemonia cultural da burguesia, para assim buscar a sua emancipação plena. 
O livro Cultura, politecnia e imagem é um prato cheio para quem busca superar a concepção idealista de cultura, compreendendo-a na sua totalidade, em diversos espaços-tempos históricos, tendo em conta as relações dialéticas entre economia, cultura e outras determinações sociais, e em especial as experiências coletivas da classe trabalhadora. Nos três eixos temáticos, o conjunto de autores desenvolve formulações teóricas com evidências empíricas de que a cultura e os processos educativos que a elegem como objeto de estudo e de compreensão da realidade podem fermentar os germes de projetos de transformação social.

\section{Referências}

KOSIK, Karel. Dialética do concreto. 2. ed. Rio de Janeiro: Paz e Terra, 1976.

THOMPSON, Edward P. Tradición, revuelta y consciência de classe. Barcelona: Crítica, 1979.

THOMPSON, Edward P. A miséria da teoria ou um planetário de erros. Rio de Janeiro: Zahar, 1981. 